\title{
Simplification in Child Language in Bahasa Indonesia: A case study on Filip
}

\author{
Julia Eka Rini
}

\begin{abstract}
This article aims at giving examples of characteristics of simplification in Bahasa Indonesia and proving that child language has a pattern and that there is a process in learning. Since this is a case study, it might not be enough to say that simplification is universal for all children of any mother tongues, but at least there is a proof that such patterns of simplification also occur in Bahasa Indonesia.
\end{abstract}

Keywords: simplification, characteristics, first language acquisition, omission, reduction, reduplication, medial, initial, final sound, consonant, vowel..

\section{Introduction}

Research in first language acquisition in Bahasa Indonesia, especially about simplification, is worth doing because of several reasons. First is because few research is done in Bahasa Indonesia, almost all research was done in English. Books about first language acquisition use examples taken from English as the mother tongue, such as Psychology and Language by Clark and Clark (1977), the chapter of First Language Acquisition in The Study of Language by George Yule (1986), and in the chapter of "Learning a First Language" in How Languages are Learned by Patsy M. Lightbown and Nina Spada (1993). In his paper "Echa Perkembangan Bahasa Anak Indonesia: Dua Belas Bulan Yang Pertama” at Pellba 9 (1995), Soenjono Dardjowidjojo also said that the research about first language acquisition had been done in English and no one, as far as he knew, had studied about Indonesian children acquisition of the mother tongue (pp. 12).

Second, studies done in Bahasa Indonesia are not about children simplification in sounds. Several students of mine conducted studies about first language acquisition in Bahasa Indonesia, but they were mainly on syntax and grammar. In the book by Clark and Clark mentioned above, they mention some characteristics in child's language, but the examples used are also English. Therefore, this article will see whether the characteristics of simplification in Clark and Clark are exactly the same in Bahasa Indonesia.

Third, simplification makes child's language difficult to understand. The child's language sounds like a new language of its own. This paper, therefore, might be helpful to understand Indonesian child's language, because there are certain characteristics that can be used as a guideline to understand it. 


\section{Review of Related Literature}

According to Clark and Clark (1977:397), some characteristics of simplification in child language are: 1)omission of final segments, 2)reduction of consonant clusters, 3)omission of unstressed syllables and 4)reduplication of syllables. These characteristics are used to see the patterns of simplification used by the subject observed.

The first characteristic is omission of final segments. Clark and Clark quoted the research result of Leopold (1949) and Menn (1971) about production of speech sound. In the research about two children, Hildegrad and Daniel, different forms of simplification are found. Most of Hildegrad's words have a simple CV structure of the initial position, while Daniel's make more use of final consonants. For example:

\begin{tabular}{|l|l|l|}
\hline \multicolumn{1}{|c|}{ Name } & \multicolumn{1}{|c|}{ Adult model } & \multicolumn{1}{c|}{ Child's pronunciation } \\
\hline Hildegrad & ball & $/ \mathrm{ba} /$ \\
\hline & pipe & $/ \mathrm{pi} /$ \\
\hline & kick & $/ \mathrm{ti} /$ \\
\hline & boot & $/ \mathrm{bu} /$ \\
\hline Daniel & stevie & $/ \mathrm{iv} /$ \\
\hline & up & $/ \wedge \mathrm{f} /$ \\
\hline & apple & $/ æ \mathrm{p} /$ (the first syllable) \\
\hline
\end{tabular}

But Clark-Clark do not classify the change of sound /p/ in up that becomes [f] in [ $\wedge f]$.

The second is reduction of consonant cluster. Simplification of consonant clusters can be done in several ways. First is by omitting the entire cluster, for example the word "cry" becomes /ai/. Second is by reducing the cluster to a single segment, for example "cry" becomes /kai/ and the last is by substituting one member of the cluster with some other sound, for example "cry" becomes /kwai/, but the commonest simplification is reduction to a single element. The child in Smith's research simplifies the cluster in this way: a) in cluster fricative /s/ + stop, the fricative /s/ is omitted, the stop remains; b) in cluster stop + liquid, the liquid is omitted, the stop remains; c) in cluster fricative + liquid or glide, the liquid or glide is omitted, the fricative remains; $d$ ) in cluster nasal + stop, the nasal is omitted and the stop remains. Thus, the stop is the segment normally retained and the other segment is the one omitted. It seems that the way of reduction is related to the order of acquisition noted by Jakobson (as cited by Clark p.399): stops, nasals, fricatives, and then liquids and glides.

The third is omission of unstressed syllables. There are three early stages of how children tackle complicated adult words. The first stage is producing one single syllables, although they hear two- and three- syllable words as well. The second stage is trying to produce one- or two- syllable words by producing only one syllable word, omitting whichever syllable is unstressed. "Children rarely attempt to pronounce longer, three-syllable, words at this stage" (Ingram as quoted by Clark). The third stage is production of both one- and two-syllable words and attempt on some three-syllable words, but they continue to omit most unstressed syllables. In two-syllable words they retain both syllables from the adult model but usually reduce unstressed vowels to the neutral vowel /e/. For example, the name Robbie is produced as /wobi/, while away becomes /we/.

The fourth is reduplication of syllables. How children reduplicate syllables varies from child to child, some never do so. First, they simplify words with two distinct 
syllables by choosing a single syllable and reduplicating it; usually both consonants and both vowels are the same. For example the word "kitchen." The syllable /ki/ is picked and the word produced is $/ \mathrm{kiki} /$. Second, later only consonants or vowels remain the same. For example, the word "blanket" becomes /babi/.

According to Smith as cited by Clark and Clark (p. 401), "these four types of simplification represent the major options young children take as they learn to produce recognizable words. These simplifications are systematic: adult models are usually discernible in the child versions of adult words.

\section{Methodology}

The subject observed here is my own son, named Filip. The observation conducted was recorded by using paper and pen when I heard Filip speak. He did not know if his utterances were written down. The utterances written here were the ones often said by Filip.

The utterances started to be recorded when he was two years old until he was three years and two months $(3 ; 2)$. Later on, the age is written in this way. The utterances are not written in phonetic symbols, because in Bahasa Indonesia the sounds are mostly the same with the written words, except a)/d/ like in besar, /é/ like in ase and è like in es b) /? / for final $k$ like in kakak, c) / /n/ for ny like in nya, / / for $n g$ like in bunga.

The data below are grouped based on characteristics of first language acquisition and are written in tables that have several columns. The first column is the age, representing the age when he uttered the word. The second is the speech produced by Filip and the third is the intended words. The fourth is the English translation of the intended words and speech produced. Sometimes one utterance can appear in several tables because there are more than one characteristic in the speech produced.

\section{Analysis and Findings}

The finding written below starts from the first characteristic and some discussion about it is written after the table. The same is done for the second, third and fourth characteristics.

The first characteristic of child language is omission of final sounds. The examples can be seen in the table 1 . 
Table 1. Omission of Final Sounds

\begin{tabular}{|l|l|l|l|}
\hline Age & Speech produced & Intended words & English translation \\
\hline $2 ; 2$ & $\grave{e}$ & es & ice \\
\hline $2 ; 3$ & $p a u$ & paus & whale \\
\hline $2 ; 3$ & $i k a$ & $i k a n$ & fish \\
\hline $2 ; 3$ & $\grave{e m i}$ & emil & his sister's name \\
\hline $2 ; 5$ & obi & mobil & car \\
\hline $2 ; 6$ & bagu & bagus & good \\
\hline $2 ; 7$ & pana & panas & hot \\
\hline $2 ; 7$ & gigi & gigit & bite \\
\hline $2 ; 7$ & $b \quad c a$ & besar & big \\
\hline $2 ; 7$ & $k$ ci & kecil & small \\
\hline $2 ; 7$ & nangi & nangis & crying \\
\hline $2 ; 7$ & naka & nakal & naughty \\
\hline 3 & atap & atas & above \\
\hline
\end{tabular}

The final sounds are omitted, like /s/, except final /s/ in atas; it is replaced with $/ \mathrm{p} /$. The medial one in besar is replaced by other sound /c/. Exception occurs to final /s/ in atas; it is replaced with $/ \mathrm{p} /$.

Table 2. Reduction of consonant clusters

\begin{tabular}{|l|l|l|l|}
\hline Age & Speech produced & Intended utterances & English translation \\
\hline $2 ; 1$ & ico & simson & Samson \\
\hline $2 ; 2$ & ëpat-ëpat & lompat-lompat & jump \\
\hline $2 ; 5$ & tebak & tembak & shoot \\
\hline $2 ; 6$ & $p$ gi & pe^rgi & go \\
\hline $2 ; 7$ & owi & snowy & teddy bear's name \\
\hline $2 ; 7$ & gapu & garpu & fork \\
\hline $2 ; 7$ & taci & taksi & taxi \\
\hline $2 ; 10$ & aji & anjing & dog \\
\hline $2 ; 10$ & tigi & tinggi & high \\
\hline 3 & $a b u t$ & rambut & hair \\
\hline $3 ; 2$ & cati? & canti? & beautiful \\
\hline
\end{tabular}

The second characteristic is reduction of consonant cluster. The examples can be seen in the table 2.

Table 3. Omission of unstressed syllables

\begin{tabular}{|l|l|l|l|}
\hline Age & Speech produced & Intended utterances & English translation \\
\hline 2 & ëa & sekolah & school \\
\hline $2 ; 1$ & ëla & sekolah & \\
\hline $2 ; 6$ & këla & sekolah & \\
\hline 2 & $u a$ & ke luar & going out \\
\hline $2 ; 1$ & ula & ke luar & \\
\hline $2 ; 5$ & kula & keluar & \\
\hline $2 ; 6$ & kulabalu & ke rumah baru & to the new house \\
\hline $2 ; 7$ & dili & sendiri & by himself \\
\hline $2 ; 9$ & kala & sekarang & now \\
\hline $2 ; 10$ & Imut & selimut & blanket \\
\hline $2 ; 11$ & olala & kelelawar & bat \\
\hline $2 ; 8$ & dakata & ndak kelihatan & cannot see \\
\hline $2 ; 8$ & dakata & ndak sengaja & not on purpose \\
\hline
\end{tabular}


The unstressed syllables are omitted, for example se and ke in sekolah and ke luar. It can be seen in the examples above that as he grows older, he omits less, such as the word sekolah and the word ke luar in table 4. In the word sekarang, for example, the omission occurs both in unstressed syllable and final sound.

The fourth characteristic is the reduplication of syllables. The examples can be seen in the table below.

Table 4. Reduplication of Syllables

\begin{tabular}{|l|l|l|l|}
\hline Age & Speech produced & Intended utterances & \multicolumn{1}{c|}{ English translation } \\
\hline 2 & moma & oma & grandma \\
\hline 2 & mimi & filip & his name \\
\hline 2 & tati & santi & his baby sitter's name \\
\hline 2 & mami & patmi & the maid's name \\
\hline 2 & nonat & donat & doughnut \\
\hline $2 ; 2$ & cace & ase & ac \\
\hline $2 ; 5$ & piti-piti & kepiting & crab \\
\hline $2 ; 5$ & tupu-tupu & tutup & lid \\
\hline $2 ; 6$ & juru? & jeru? & orange \\
\hline $2 ; 6$ & bulu & belum & not yet \\
\hline $2 ; 6$ & pipo & simson & Samson \\
\hline $2-2 ; 11$ & cici & kelinci & rabbit \\
\hline $2 ; 6$ & guk-guk & anjing & dog \\
\hline $2 ; 9$ & cucucucua & susunan & jigsaw puzzle \\
\hline $2 ; 11$ & tenginga & telinga & ear \\
\hline
\end{tabular}

The word donat, for example, is the reduplication of the stressed second syllable. The first unstressed syllable is omitted and the [n] in the second syllable is used in the first syllable. The same thing occurs with patmi. Tupu-tupu is also used for the words kupukupu. For the word simson for example, two ways of reduplication occur. The first is that only the vowels remain and the speech produced is pipo. The letters "ng" is one sound in Bahasa Indonesia and the reduplication occurs by replacing /// with the last consonant. In jeruk and belum the vowels are reduplicated.

Besides the four characteristics mentioned above, another characteristic found in the utterances is the omission of initial sound (table 5).

Table 5. Omission of initial sounds

\begin{tabular}{|l|l|l|l|}
\hline \multicolumn{1}{|c|}{ Age } & \multicolumn{1}{c|}{ Speech produced } & \multicolumn{1}{c|}{ Intended words } & \multicolumn{1}{c|}{ English translation } \\
\hline 2 & ini & sini & here \\
\hline $2 ; 1$ & ia & via & his sister's name \\
\hline $2 ; 1$ & mi & emil & his sister's name \\
\hline $2 ; 1$ & $u k a$ & suka & like \\
\hline $2 ; 2$ & ëpat-ëpat & lompat-lompat & jump \\
\hline $2 ; 5$ & obi & mobil & car \\
\hline $2 ; 6$ & apu & lampu & lamp \\
\hline $2 ; 6$ & apu & sapu & broom \\
\hline $2 ; 6$ & ana & sana & there \\
\hline $2 ; 7$ & amu? & nyamu? & mosquito \\
\hline $2 ; 7$ & inga & singa & lion \\
\hline $2 ; 7$ & uap & suap & feed \\
\hline $2 ; 7$ & ati? & canti? & beautiful \\
\hline $2 ; 10$ & uda & sudah & already \\
\hline
\end{tabular}




\section{\begin{tabular}{l|l|l}
$2 ; 10$ & filip & \\
\hline
\end{tabular}}

Sometimes omission occurs both the sound in initial and final position like the word mobil. $u d a$ is produced although he always hears the word sudah. This word is grouped in the omission of initial sound only because the sound $[\mathrm{h}]$ is weak in Bahasa Indonesia. It is different from the sound [1] in mobil.

Another characteristic found in the utterances is the reversion of vowel or consonants both in the same syllable or different syllables.

Table 6. Examples of reversion of vowels/consonants

\begin{tabular}{|l|l|l|l|}
\hline Age & Speech produced & Intended utterances & English translation \\
\hline 2 & cé & es & ice \\
\hline $2 ; 6$ & ñèmot & monyet & monkey \\
\hline $2 ; 6$ & ëpici & polisi & police \\
\hline $2 ; 6$ & dago-dago & gado-gado & vegetables salad \\
\hline $2 ; 7$ & citana & istana & palace \\
\hline
\end{tabular}

The example of vowel and consonant reversion is monyet becomes nyemot or emot, especially in tope emot (topeng monyet).

Starting the age of 2;9 he identifies suffixes, such as nya and an. These examples actually belong to the first characteristic, but they are discussed separately here because the suffixes are recognized as separate words by the subject (table 7).

Table 7. Characteristics of suffixes

\begin{tabular}{|l|l|l|l|}
\hline Age & Speech produced & Intended utterances & \multicolumn{1}{|c|}{ English translation } \\
\hline $2 ; 9$ & papa a & papaña & his/her papa \\
\hline $2 ; 9$ & mama a & mamaña & his/her mama \\
\hline $2 ; 9$ & mai a & mainan & toy \\
\hline $2 ; 9$ & cucu cucu a & susunan & puzzle \\
\hline $3 ; 2$ & dilika & sendirian & alone \\
\hline $3 ; 2$ & duluka & duluan & ahead \\
\hline $3 ; 2$ & pedeka & kepedesan & hot because of chilly \\
\hline $3 ; 2$ & bakaka & kebakaran & on fire \\
\hline $3 ; 2$ & kuda-kudaka & kuda-kudaan & horse game \\
\hline
\end{tabular}

Suffix nya undergoes omission of initial sound, while suffix an undergoes omission of final sound in the first stage. In the second stage it is changed to $k a$.

The characteristics above happens also when he imitates English songs or phrases as follows.

Table 8. Characteristics in English songs/phrases

\begin{tabular}{|c|c|c|}
\hline Number & Speech produced & Intended utterances \\
\hline 1 & titita’dné & sing sweet nightingale \\
\hline 2 & pitopapito & it's home from work we go \\
\hline 3 & opici èddmi & police academy \\
\hline 4 & $e d \partial b i$ & beauty and the beast \\
\hline
\end{tabular}

In the first example in table 8 the sentence is taken from the song in the film "Cinderella." From the word "sing" vowel /i/ is taken and reduplication occurs; sing sweet becomes /titi/. The diphthong ./ai/ and /ei/ in "nightingale are reduced to single 
sound /a/ and /e/. "nightingale" becomes jné by reversing n (night) and t (tingale); /i/ in "ti" is lowered to $\partial /$. The reduction of the diphthong can be seen when he speaks a sentence, for example: /mimi mo ni/ (read: filip mau ini). The second example is taken from the song sung by the seven dwarfs in the film "Snow White and the Seven Dwarfs." Here only the vowels are taken; the vowel /i/ and /o/ in it's home with the reduction of /ou/ from "home." The same thing happens to "we go." "From work" is not clear in the song and "from" is emphasized; so the vowel /a/ is taken and reduplication happens. In the third example the word "police" is taken from Bahasa Indonesia because Filip saw the film and he knows that the man in uniform like that is opici. In the word "academy" the stressed second syllable is omitted. In the last example, the word "beauty" is dropped and only "and the beast" which is produced as one word $e d e^{\wedge} b i$. In these examples only the third example is different concerning the omitted stressed syllable, while usually it is the unstressed syllable is omitted.

Another interesting finding is that there is a change in sound $/ \mathrm{s} /$. Initial and medial /s/ become /c/, for example in table 1, 3 and 6: /beca / (besar), /opici/ (polisi), /citana/ (istana), /ico/( Simson), /taci/ (taxi), /cucucucu a/ (susunan), while final /s/ is omitted like in è (es), except in reduplication like /tati/ (santi). One exception occurs in final /s/ atap (atas), $s$ is replaced by $p$.

\section{Conclusion}

All the four characteristics exist in the data and there are two other characteristics, namely omission of initial sound and reversion of vowel or consonant. Suffix is recognized as individual syllable and undergoes the same process like individual words, the final sound is omitted (for example $a$ for an or nya) or reversion happens (for example $k a$ for $a n$ ). Since this is a case study on one subject only, the two additional characteristics cannot be generalized for all Indonesian children. Similarities are found in the four characteristics of simplification and the rule for the reduction of consonant cluster in English also exist in the data. It is not in the reduction of consonant cluster in Bahasa Indonesia, but the production of initial and medial $/ \mathrm{s} /$.

\section{References}

Clark, Herbert H and Eve V. Clark. (1977). "First Sounds in the Child's language" in Psychology and Language: An Introduction to Psycholinguistics. New York: Harcourt Brace Jovanovich, Inc.

Dardjowidjojo, Soenjono. "Echa Perkembangan Bahasa Anak Indonesia: Dua Belas Pellba 9. Jakarta: Lembaga Bahasa Unika Atmajaya.

Departemen Pendidikan dan Kebudayaan. (1988). Tata Bahasa Baku Bahasa Indonesia. Jakarta: Balai Pustaka

Yule, George. (1996). The Study of Language. $2^{\text {nd }}$ edition. Cambridge: Cambridge University Press. 